\title{
Alternative Electrocoagulation for Livestock Wastewater Treatment
}

\author{
José Pinedo-Hernández, ${ }^{*}$ Roberth Paternina-Uribe \\ and José Marrugo-Negrete \\ University of Córdoba, Faculty of Basic Sciences, Department of Chemistry, Water, Applied \\ and Environmental Chemistry Group, Monteria, Colombia
}

Received May 17, 2016; accepted August 23, 2016

\begin{abstract}
This project assessed the technical feasibility of organic matter (COD) removal in livestock effluents, by electrocoagulation. An experimental design was used to block two factors at three levels, to evaluate the effect of the variables distance between electrodes and $\mathrm{pH}$, using aluminum sacrificial electrodes. Maximum removal $(90.16 \%)$ was obtained at 7 units $\mathrm{pH}$, and $2.0 \mathrm{~cm}$ distance between electrodes. This study demonstrated the technical feasibility of electrocoagulation (EC) for the removal of organic matter as COD, present in wastewater from the livestock industry.
\end{abstract}

Keywords: Livestock effluents, Electrocoagulation, Chemical Oxygen Demand (COD).

\section{Introduction}

Colombian livestock represents a very important sector for the economy's main axis of the Caribbean region, especially in the department of Córdoba, due to certain geographical conditions characteristic of the area [1]. In livestock industry, the wastewater generated as cattle bath product represents a great threat to the environment; it contains traces of recalcitrant pesticides, toxic compounds and high levels of organic matter [2]. Electrocoagulation (EC) may be used as an alternative system of wastewater treatment, because it is inexpensive, the equipment used is simple and of easy operation, compared to the conventional methods (chemical coagulation), no chemical substances are used, and produces large and more stable flocs than those formed by chemical coagulation $[3,4]$. Electrocoagulation is receiving an increasing acceptance by industry, in view of its advantages compared to other methods. The method is based on anodic dissolution of metallic aluminium and the formation of aluminium ions in the vicinity of the anode, these ions being immediately converted to the corresponding hydroxides. The hydroxide, in the process of coagulation and flocculation, has highly adsorptive and adherent qualities, and is colloidally

\footnotetext{
* Corresponding author. E-mail address: josejph@hotmail.com
} 
dispersed. When a current is passed through $\mathrm{Al}$ anodic dissolution, it takes place according to the following reaction:

$$
\mathrm{Al} \rightarrow \mathrm{Al}^{3+}+3 \mathrm{e}^{-}
$$

Simultaneously, water is reduced at the cathode to hydrogen gas and hydroxyl ion $\left(\mathrm{OH}^{-}\right)$

$$
2 \mathrm{H}_{2} \mathrm{O}+2 \mathrm{e}^{-} \rightarrow 2 \mathrm{OH}+\mathrm{H}_{2}
$$

Thus, electrocoagulation introduces metal cations in situ, electrochemically, using sacrificial anodes. $\mathrm{Al}^{3+}$ hydrolyzes in water, forming the corresponding hydroxide; Eqs. (3) - (5) illustrate this, in the case of aluminium anode charge on the organic matter, which is responsible for the stability:

$$
\begin{gathered}
\mathrm{Al}^{3+}+\mathrm{H}_{2} \mathrm{O} \rightarrow \mathrm{AlOH}^{2+}+\mathrm{H}^{+} \\
\mathrm{AlOH}^{2+}+\mathrm{H}_{2} \mathrm{O} \rightarrow \mathrm{Al}(\mathrm{OH})^{2+}+\mathrm{H}^{+} \\
\mathrm{Al}(\mathrm{OH})^{2+}+\mathrm{H}_{2} \mathrm{O} \rightarrow \mathrm{Al}(\mathrm{OH})_{3}+\mathrm{H}^{+}
\end{gathered}
$$

The main objective of this study was to evaluate the removal of organic matter (COD) in livestock effluents by electrocoagulation, controlling $\mathrm{pH}$ and distance variables between electrodes.

On this basis, it was expected that using $\mathrm{Al}$ anode would improve the process of electrocoagulation, through enhancing the rate of mass transfer of $\mathrm{Al}^{3+}$ from the anode surface to the bulk solution, to be applied to continuous flow process. This would reduce the concentration of polarization, and hence, reduce the passivation tendency of the anode, which adversely affects the process of electrocoagulation.

\section{Materials and methods}

\section{Sample collection and preservation}

Wastewater sample under study was taken from a cattle farm in the town of Monteria, Cordoba - Colombia, in a day of cattle bath. Effluents were collected in plastic tanks, sufficient for processing in the EC system. The processing was performed before and after $\mathrm{pH}$ treatment, and the COD analysis was based on Standard Methods $4500 \mathrm{H} \mathrm{B}$ and $5220 \mathrm{D}$ [5] procedures references. Initial $\mathrm{pH}$ and COD were 6.5 units and $680 \mathrm{mg} \mathrm{L}^{-1}$.

\section{Electrocoagulation cell}

Fig. 1 shows the experimental scheme of the EC process. Volume was used for each 4.0 L test sample. Six iron electrodes in the reactor were used as cathodes, and three aluminium anodes with effective dimensions of $18 \times 2.5 \times 0.5 \mathrm{~cm}$ were connected to DC - PHYWE 0-50 V fluent potential. The entire submerged surface of every electrode was $25 \mathrm{~cm}^{2}$. 


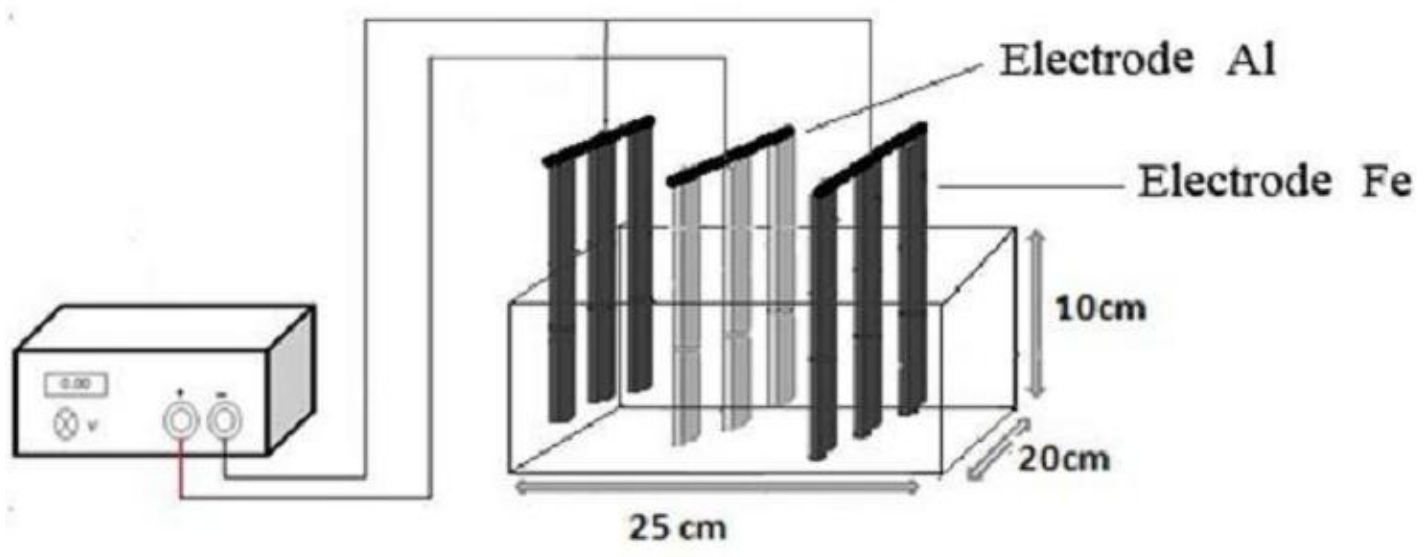

Figure 1. Electrocoagulation cell.

\section{Experimental design}

Statgraphics Centurion 15.2.06 software was used for the statistical design of experiments and data analysis. The two most important operating variables, initial wastewater $\mathrm{pH}$ (x1) and distance (x2), were optimized for both wastewaters. Their range and levels are shown in Table 1. Levels of every factor were evaluated in triplicate; there were 27 essays in the whole process. Percentage of COD removal was established as the response variable. Time and potential were $30 \mathrm{~min}$ and $50 \mathrm{~V}$. Aluminium was used as sacrificial electrode. Fixed variables sets were selected based on tests conducted by Mestra and Pineda [6].

Table 1. Experimental design factors and levels.

\begin{tabular}{lllcl}
\hline Independent variable & Factor & \multicolumn{3}{c}{ Range and level } \\
\cline { 2 - 5 } & $\mathrm{Xi}_{\mathrm{i}}$ & -1 & 0 & 1 \\
$\mathrm{pH}$ & $\mathrm{X}_{1}$ & 4.0 & 7 & 8.0 \\
Distance $(\mathrm{cm})$ & $\mathrm{X}_{2}$ & 2.0 & 3.5 & 5.0 \\
\hline
\end{tabular}

\section{Statistical analysis}

The data were submitted to ANOVA test, and mean comparisons were performed when needed using Tukey tests. Response Surface Methodology (RSM) was applied to evaluate the simple and combined effects of three independent parameters on removal and optimizing of the operating conditions. Statgraphics Centurion 15.2.06 statistical software was used for all analysis. A significance level of 0.05 was selected. 


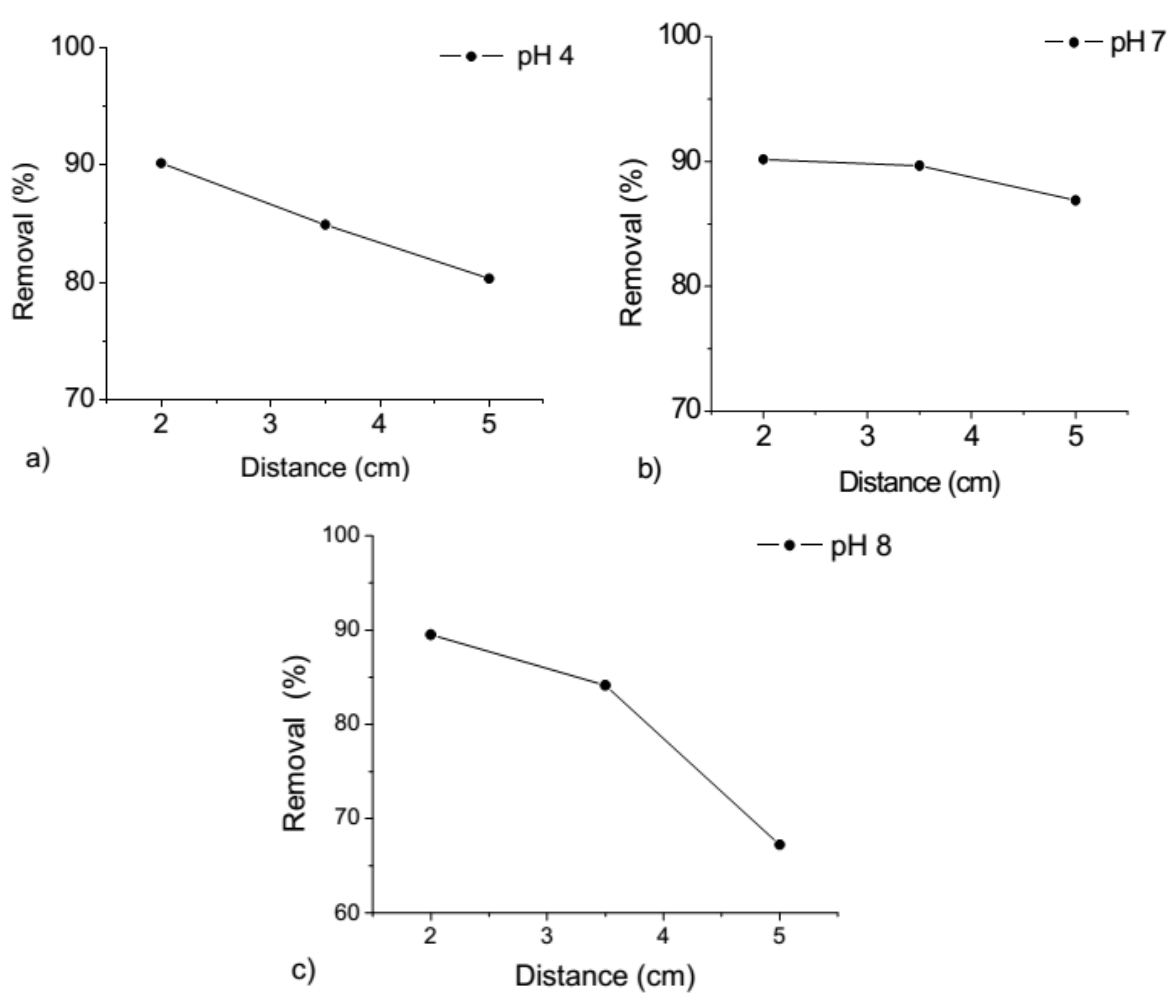

Figure 2. COD removal: $\mathrm{pH} 4$ (a), $\mathrm{pH} 7$ (b) and $\mathrm{pH} 8$ (c).

\section{Results and discussion \\ COD removal function of $\mathrm{pH}$ and distance}

The removal of COD in function of $\mathrm{pH}$ and distance between electrodes is shown in Fig. 2. Removal values are higher than $80 \%$ at initial $\mathrm{pH}$ of 4 and 7 , independently of distance. However, initial $\mathrm{pH}$ of 8 and $5 \mathrm{~cm}$ distance show $67.21 \%$ removal (Fig. 2c). It is observed that decreasing the distance between electrodes increases the removal of COD, reaching maximum values $(>80 \%)$ at a distance of $2 \mathrm{~cm}$ for different $\mathrm{pH}$ values. This is possibly due to the electrostatic field formed during the electrocoagulation process, which depends on the distance between electrodes [7-8], and causes the metal ions production by the anode (sacrificial electrode): its function is to destabilize loads possessing contaminant particles present in water, neutralize the systems that keep the particles in suspension - allowing the formation of aggregates of contaminants, and initiating the coagulation process in less time, with higher removal [9].

Fig. $2 \mathrm{~b}$ shows that, at $\mathrm{pH} 7, \mathrm{COD}$ removal decreases according to the distance, with no statistically significant difference $(\mathrm{p}>0.05)$, unlike $\mathrm{pH} 4$ and 8 , which have a statistically major difference $(\mathrm{p}<0.05)$. This can be attributed to $\mathrm{pH}<7$, because the formed hydroxides are not stable enough to react with the aluminum cation, not allowing coagulant formation [10-12]. A pH near 7 facilitates the generation of hydroxyl radicals and, in its turn, the formation of agglomerates, which are ultimately removed from the solution [13]. With $\mathrm{pH}$ values $>7$ the oxidative potential in question decreases; this justifies the reduction in the removal of reactions involved in the process, and therefore, a decrease in pollutant removal [14]. 


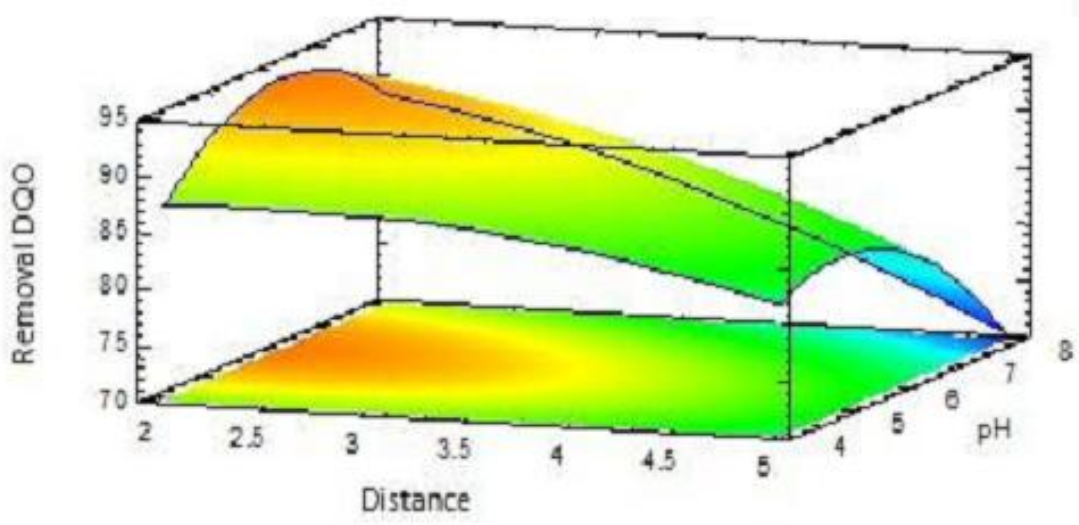

Removal DQO

Figure 3. Response surface removal of COD.

\section{Optimization of the treatment conditions}

The application of RSM based on the parameters estimation generates the second order regression model, where the removal percentage of COD (y) and the independent variables studied are related (Eq. 6).

$y=90.4033-5.89833 * x 1-2.40333 * x 2-2.245 * x_{1}^{2}-6.18 * x_{2}^{2}-3.1175 * x_{1} * x_{2}$

The coefficient of determination $\left(\mathrm{r}^{2}\right)$ was 0.843 , which implies that $84.3 \%$ of the variations in COD removal are explained through independent variables, and $15.7 \%$ of variations cannot be explained by the model. According to Montgomery [15], it is satisfactory that $\left(\mathrm{r}^{2}\right)$ is at least $75 \%$, when considering proceeding with the methodology. The model generates the optimum values for the maximum COD removal, as a function of $\mathrm{pH}$ and distance. The response surface calculated on the basis of the model (Fig. 3) allows visualizing the behavior of the response variable, and clearly indicates the factors levels combination that leads to a maximum value. In this study, it is observed that the best results are in the orange region, where factors interaction leads to results between 92.5 and $95 \%$.

Significant differences were not observed $(\mathrm{p}<0.05)$ when the response was compared to the corresponding experimental value, which confirms that RSM can be used to optimize the process parameters (Table 2). Additionally, it is observed that the results of the second order regression model present significant correlations with the experimentally obtained results $(r=0.996, p=0.01, n=27$; Fig. 4).

Table 2. Optimum values of the process parameters for COD removal.

\begin{tabular}{ccc}
\hline Parameter & Optimum value & Experimental value \\
\hline Removal $(\%)$ & 94.08 & 92.43 \\
pH & 6.11 & 6.1 \\
Distance $(\mathrm{cm})$ & 2.0 & 2.0 \\
\hline
\end{tabular}




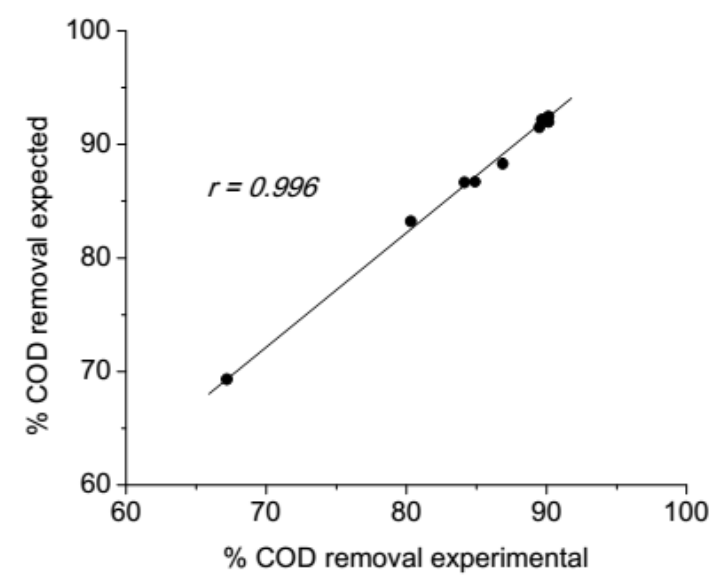

Figure 4. Experimental percentage of COD removal and percentage of mercury removal predicted by the second order model regression.

The variance analysis is shown in Table 3. It is observed that the independent variables are not statistically significant $(p>0.05)$. However, the distance factor has a value close to 0.05 , which can reveal the removal difference based on this factor.

To assess the adequacy of the developed model, the difference between Experiment and Predicted (waste) response is used to graphically analyze the effectiveness of the model. Waste is considered as unexplained variations by the model, and they will have a normal distribution if the model accurately predicts normal residue probability graph and normal distribution. This should give a linear fashion, and graphic of residuals versus predicted values should represent a random pattern of residues around zero [16]. Fig. 5a shows the normal probability graph waste for use as Al anode electrode in the optimization model for COD removal from effluents of livestock industry, where it meets the criteria of statistical normality by its linear trend. Fig. 5b shows the graph of actual versus predicted residuals for the removal of COD, exhibiting a random pattern around zero waste, which represents a normal distribution.

Table 3. Variance analysis.

\begin{tabular}{|c|c|c|c|c|c|}
\hline Source & Sum of squares & Gl & Mean square & Value-F & Value-P \\
\hline A:Distance & 208.742 & 1 & 208.742 & 9.14 & 0.0506 \\
\hline B:pH & 34.6561 & 1 & 34.6561 & 1.52 & 0.3058 \\
\hline AA & 10.0801 & 1 & 10.0801 & 0.44 & 0.5540 \\
\hline $\mathrm{AB}$ & 38.8752 & 1 & 38.8752 & 1.70 & 0.2831 \\
\hline BB & 76.3848 & 1 & 76.3848 & 3.34 & 0.1649 \\
\hline Total error & 68.5358 & 3 & 22.8453 & & \\
\hline Total (corr.) & 437.274 & 8 & & & \\
\hline
\end{tabular}

The electrical energy consumption was calculated in terms of KHz. $E(\mathrm{kWh})=$ $U^{*} I^{*} t / 1000$, where $\mathrm{U}$ is cell voltage (V), I is current $(\mathrm{A}), \mathrm{t}$ is the time of $\mathrm{EC}(\mathrm{h})$. The implementation of EC unit in large scale level mainly depends on the treatment process cost. In order to find out the economy of the proposed treatment method, the economic evaluation was made in optimum operating 
conditions. It was found that the energy supplied to wastewater treatment by EC is $0.03 \mathrm{KHz}$, given that $\mathrm{KHz}$ price in Colombia (\$ 349.7; \$US 0.13) is \$ 4.37 for volume of solution $\left(0.004 \mathrm{~m}^{3}\right)$, i.e., $1092.8 \$ / \mathrm{m}^{3}\left(0.39 \$ \mathrm{US} / \mathrm{m}^{3}\right)$. Related to the consumption of Al per test $(0.0643 \mathrm{~g} / \mathrm{L})$ by $\mathrm{m}^{3}\left(64.25 \mathrm{~g} / \mathrm{m}^{3}\right)$, the A1 material price $(\$ 4313.7 / \mathrm{kg})$ is obtained by $\mathrm{m}^{3}\left(\$ 277.2 / \mathrm{m}^{3} ; \$ 0.11 \mathrm{US} / \mathrm{m}^{3}\right)$. This result illustrates the economical feasibility of the proposed treatment in the on-field implementation, i.e., wastewater treatment plants (WTP's). $\mathrm{pH}$ and temperature should be taken into account to develop processes to improve electrocoagulation process. It has been determined in some cases that greater removal of a contaminant occurs within a specific $\mathrm{pH}$ range. This range can be even wider. In general, the literature indicates that the best removals were obtained for $\mathrm{pH}$ values close to 7 , which improves electrocoagulation process [18].

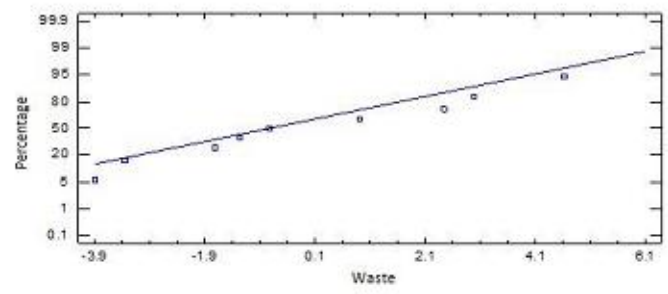

a)

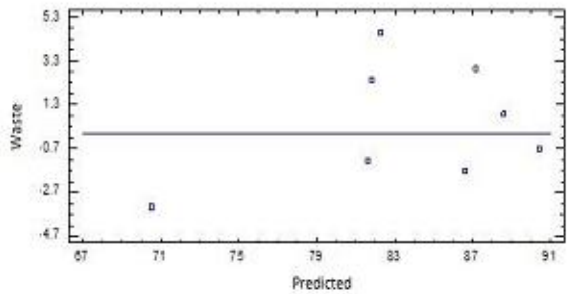

b)

Figure 5. a) Normal probability plot waste. b) Graphic waste.

The pre treatment temperature was $28{ }^{\circ} \mathrm{C}$, and post treatment temperature increased $2{ }^{\circ} \mathrm{C}$. Chen [19] indicates that the system temperature must be lower than or equal to $60{ }^{\circ} \mathrm{C}$, to achieve greater removal.

\section{Conclusions}

Electrocoagulation (EC) and effluent treatment bath livestock is a technically viable alternative for the removal of organic matter as COD. The results showed that, for a distance between electrodes of $2 \mathrm{~cm}$, COD removal percentage was significantly higher. The applied electrochemical treatment allowed the removal of COD in $90.16 \%$, under conditions of optimal electrocoagulation: $\mathrm{pH}$ (7.0), distance $(2 \mathrm{~cm})$, voltage $(50 \mathrm{~V})$, time $(30 \mathrm{~min})$. These results indicated that electrochemical treatment process is an effective treatment method, in terms of removal efficiency, with reasonable operating costs.

\section{Acknowledgements}

The authors wish to thank the Water, Applied and Environmental Chemistry Group, Laboratory of Toxicology and Environmental Management, University of Cordoba, Montería-Colombia.

\section{References}

1. Lombana J, Martínez D, Valverde M, et al. Caracterization the livestock sector of the Colombian Caribbean. Editorial Universidad del Norte; 2012. 
2. Barrios J, Yepez J. Evaluation model of solar photocatalytic degradation kinetic in a cpc reactor of pesticide used in the bathroom of cattle. Graduation Project: Universidad de Cartagena, Facultad de Ingeniería, Cartagena-Colombia; 2010.

3. Rios GB, Almerava F, Herrera MT. Electrode Passivation in the Electrocoagulation Process. Port Electrochim Acta. 2005;23:17-35.

4. Holt PK, Barton GW, Mitchell CA. The future for electrocoagulation as a localised water treatment technology. Chemosphere. 2005;59:355-367.

5. APHA, Standard Methods for the Examination of Water and Wastewater. 21th ed. Washington, DC: American Public Health Association, American Water Works Association, Water Pollution Control Federation; 2005.

6. Mestra D, Pineda R. Electrocoagulación como alternativa para el tratamiento de aguas residuales del baño de ganado bovino en el departamento de Córdoba. Universidad de Córdoba, Colombia; 2015.

7. Holt P, Barton G, Mitchell C. Electrocoagulation as a Wastewater Treatment. The Third Annual Australian Environmental Engineering Research Event; 1999.

8. Daneshvar N, Sorkhabi HA, Kasiri MB. Decolorization of dye solution containing Acid Red 14 by electrocoagulation with a comparative investigation of different electrode connections. $\mathrm{J}$ Hazard Mater. 2004; 112:55-62.

9. Chen G. Electrocoagulation and Electroflotation of Restaurant Wastewater. J Environ Eng. 2000;126:858-863.

10. Chen G. Electrochemical technologies in wastewater treatment. Sep Purifi Technol. 2004;38:11-41.

11. Kumar P, Chaudhari S, Khilar K, et al. Removal of arsenic from water by electrocoagulation. Chemosphere. 2004;55:1245-1252.

12. Bayramoglu M, Kobya M, Can O, et al. Operating cost analysis of electrocoagulation of textile dye wastewater. Sep Purif Rev. 2004;37:117125.

13. Heidmann I, Calmano W. Removal of $\mathrm{Zn}$ (II), Cu (II), Ni (II), Ag (I) and $\mathrm{Cr}$ (VI) present in aqueous solutions by aluminium electrocoagulation. J Hazard Mater. 2008;152:934-941.

14. Linares I, Martínez V, Barrera C, et al. Oxidation of persistent organic matter in industrial wasterwater by electrochemical treatments. Avances Ciencias Ingeniería. 2011;2:21-36.

15. Montgomery DC. Design and analysis of experiments. Nebraska: John Wiley \& Sons; 2000.

16 Sarabia LA, Ortiz MC. Response surface methodology. In: Brown SD, Tauler R, Walczak B. editors. Comprehensive chemometrics. Oxford: Elsevier; 2009. pages 345-390.

17. Thirugnanasambandham K, Sivakumar V, Maran JJP. Response surface modelling and optimization of treatment of meat industry wastewater using electrochemical treatment method. J Taiwan Inst Chem Eng. 2015;46:160167. 
18. Chen G. Electrochemical Technologies in Wastewater Treatment. Sep Purif Technol. 2004;38:11-41.

19. Chen G, Chen X, Yue PL. Electrocoagulation and electroflotation of restaurant wastewater. J Environ Eng. 2000;858-863. 